\title{
Indeks Glikemik, Kandungan Gizi, dan Daya Terima Puding Ubi Jalar Putih (Ipomoea batatas) dengan Penambahan Buah Naga Merah (Hylocereus polyrhizus)
}

\section{Glycemic Index, Nutrient Content, and The Acceptance Capability Sweet Potato (Ipomoea batatas) Pudding with Addition of Red Dragon Fruit (Hylocereus polyrhizus)}

Ruly Dwi Arysanti ${ }^{1}$, Sulistiyani ${ }^{2}$, Ninna Rohmawati ${ }^{3}$

\begin{abstract}
ABSTRAK
Latar Belakang: Diabetes melitus merupakan salah satu penyakit degeneratif yang mengalami peningkatan prevalensi setiap tahunnya. Pengaturan diet dengan pemilihan jenis dan jumlah makanan berindeks glikemik rendah merupakan salah satu cara yang dapat dilakukan oleh diabetisi dalam penatalaksanaan diet. Peneliti ingin memodifikasi puding ubi jalar putih dengan penambahan buah naga merah untuk mendapatkan produk pangan dengan indeks glikemik dan kadar karbohidrat rendah serta kadar serat tinggi.

Tujuan: Penelitian ini bertujuan untuk menganalisis indeks glikemik, kandungan gizi (kadar karbohidrat dan kadar serat) serta daya terima puding ubi jalar putih dengan penambahan buah naga merah sebesar $25 \%$, 50\%, dan $75 \%$.

Metode: Metode penelitian yang digunakan adalah true eksperimental dengan post-test only control design. Subjek penelitian sebanyak 10 orang mahasiswa untuk uji indeks glikemik dan 25 orang penderita diabetes melitus untuk uji daya terima.

Hasil: Indeks glikemik puding dengan 4 taraf perlakuan (K, P1, P2, dan P3) adalah 37,75; 33,81; 32,81; dan 29,54. Semakin tinggi penambahan buah naga merah dapat menurunkan kadar karbohidrat dan kadar serat puding. Puding dengan penambahan buah naga merah $75 \%$ adalah puding yang paling disukai oleh panelis.

Kesimpulan: Kesimpulan dari penelitian ini yaitu tidak terdapat perbedaan yang signifikan terhadap penambahan buah naga merah pada puding ubi jalar putih. Penambahan buah naga merah memiliki perbedaan yang signifikan terhadap kadar karbohidrat, dan kadar serat. Puding tersebut diterima oleh panelis dari segi rasa, tekstur, aroma, dan warna, tetapi berdasarkan hasil statistik hanya daya terima rasa yang memiliki perbedaan yang signifikan.
\end{abstract}

Kata kunci: puding, buah naga merah, diabetes

\section{ABSTRACT}

Background: Diabetes mellitus is one of the degenerative diseases that have increased prevalence every year. Diet arrangement by the selection of type and amount which a low glycemic index are methods that can applied by diabetic in diet implementation. Researchers want to modify the white sweet potato pudding with addition of red dragon fruit to obtain low glycemic index, low carbohydrate, and high fiber food products.

Objective: The purpose of this study was to analyze the glycemic index, nutrient content, and the acceptance capability of white sweet potato pudding with addition of red dragon fruit by $25 \%, 50 \%$, and $75 \%$.

Method: The research method used is true experimental with post-test only control design. The researcher subject were 10 student for index glicemyc test and 25 diabetics patient for acceptance capability.

Result: The pudding glycemic index with 4 treatment (K, P1, P2, and P3) were 37.75; 33.81; 32.81; and 29.54. The higher addition of red dragon fruit can pudding low carbohydrate and fiber level. Pudding with addition of $75 \%$ red dragon fruit was the the most preferred pudding by panelists.

Conclusion: In conclusion, there was no significant difference in the addition of red dragon fruit to white sweet potato pudding. The addition of red dragon fruit had a significant difference in carbohydrate levels, and fiber content. The pudding was well received by the panelists in terms of taste, texture, aroma, and color, but based on the statistical results only the taste received had a significant difference.

Keywords: pudding, red dragon fruit, diabetes 


\author{
*Korespondensi: \\ rulyarysanti@gmail.com \\ 1,2,3Bagian Gizi Kesehatan Masyarakat, Fakultas Kesehatan Masyarakat, Universitas Jember \\ Jalan Kalimantan 37, 68121, Jember, Jawa Timur, Indonesia
}

\section{PENDAHULUAN}

Indonesia merupakan salah satu negara yang mengalami transisi epidemiologi yang ditandai dengan adanya perubahan mortalitas dan morbiditas yang disebabkan oleh penyakit infeksi/ penyakit menular menjadi penyakit tidak menular dan penyakit degeneratif. Salah satu penyakit degeneratif yang mengalami peningkatan prevalensi secara terus menerus adalah diabetes melitus. Diabetes melitus adalah kumpulan gejala yang timbul pada seseorang yang mengalami peningkatan glukosa darah akibat kekurangan hormon insulin secara absolut atau relatif ${ }^{1}$. Salah satu penatalaksanaan diet diabetes adalah pengaturan diet dengan pemilihan jenis dan jumlah makanan berindeks glikemik rendah. Indeks glikemik adalah skala atau angka yang diberikan pada makanan tertentu berdasarkan seberapa cepat makanan tersebut meningkatkan kadar gula darahnya, skala yang digunakan adalah $1-100^{2}$. Pangan berindeks glikemik rendah memiliki potensi untuk dijadikan makanan dalam terapi diet diabetes melitus, salah satunya adalah ubi jalar putih dan buah naga merah yang memiliki indeks glikemik 54 dan 37. Kadar karbohidrat dan serat ubi jalar putih yaitu 20,60 gram dan 4,00 gram, sedangkan pada buah naga merah yaitu 12,38 gram dan 1,7 gram. Pemilihan buah naga merah dalam penelitian ini karena harga murah, mudah didapat, warna menarik, dan kandungan gizi tidak berubah dan hilang meskipun telah melalui proses pemanasan.

Pengembangan produk pangan menjadi salah satu solusi untuk diversifikasi makanan bagi penderita diabetes, dimana penderita diabetes memerlukan makanan selingan 2-3 kali porsi. Penderita diabetes seringkali mengabaikan makanan selingan dan merasa cukup dengan makanan utama saja, hal ini akan memperbesar risiko terjadinya komplikasi. Produk pangan dalam penelitian ini adalah puding ubi jalar putih dengan penambahan buah naga merah dengan berbagai proporsi. Puding ini diharapkan memiliki kadar karbohidrat rendah dan kadar serat tinggi. Pemilihan puding dikarenakan puding merupakan makanan yang digemari oleh seluruh lapisan usia, memiliki tekstur lembut, dan rasa segar, serta praktik dalam pengolahannya. Kadar serat dalam makanan bermanfaat untuk mengontrol berat badan atau kegemukan, menanggulangi penyakit diabetes, mencegah gastrointestinal, mencegah kanker kolon, dan mengurangi kolesterol serta penyakit kardiovaskuler ${ }^{3}$. Selain itu, terdapat penelitian mengenai pemberian jus buah naga merah selama 10 hari berturut-turut dengan 200 gram jus buah naga merah mampu menurunkan kadar glukosa darah dan kolesterol secara signifikan ${ }^{4}$.

Berdasarkan permasalahan tersebut, rumusan masalah dalam penelitian ini adalah bagaimana pengaruh indeks glikemik, kandungan gizi berupa kadar karbohidrat, dan kadar serat, serta daya terima puding ubi jalar putih dengan penambahan buah naga merah sebesar $25 \%$, 50\%, dan $75 \%$. Penelitian bertujuan untuk menganalisis indeks glikemik, kandungan gizi berupa kadar karbohidrat dan kadar serat, serta daya terima puding ubi jalar putih dengan penambahan buah naga merah sebesar $25 \%$, 50\%, dan $75 \%$.

\section{METODE}

Metode penelitian yang digunakan adalah true eksperimental dengan post-test only control design. Penelitian ini dilakukan pada bulan Maret-Mei 2018. Uji indeks glikemik dilakukan di Fakultas Kesehatan Masyarakat, uji karbohidrat dan serat di Laboratorium Analisis Pangan Politeknik Negeri Jember, dan daya terima di Klinik dr. Suherman Universitas Muhammadiyah Jember. Sampel penelitian adalah ubi jalar putih, buah naga merah, gula diabetasol dan tepung agar-agar.

Berdasarkan tabel 1 dapat dilihat bahwa pada kelompok kontrol, puding hanya terbuat dari ubi jalar putih, tepung agar-agar, dan gula, sedangkan untuk perlakuan 1 sampai 3 puding ubi jalar putih ditambahkan buah naga merah dengan presentase yang telah ditentukan.

Subjek penelitian indeks glimemik adalah 10 orang mahasiswa yang masuk dalam kriteria inklusi. Kriteria inklusi pengujian indeks glikemik adalah dalam keadaan sehat (non-diabetes), memiliki kadar glukosa darah puasa normal $(70-120 \mathrm{mg} / \mathrm{dL}$, umur $18-23$ tahun, IMT normal $\left(18,5-24,9 \mathrm{~kg} / \mathrm{m}^{2}\right)$ dan bersedia menjadi subjek penelitian, sedangkan kriteria ekslusi adalah penderita diabetes ataupun kadar glukosa puasa normalnya $>120 \mathrm{mg} / \mathrm{dL}$. Subjek berpuasa sekurangnya 10 jam, lalu diambil dan diperiksa kadar glukosa darahnya, 10 menit kemudian diberi beban glukosa murni 50 gram dalam segelas air $(200 \mathrm{ml})$. Subjek diambil dan diperiksa kembali glukosa darahnya 30 menit setelah beban diberikan. Selanjutnya diperiksa kembali dalam waktu 60 menit, 90 menit dan terakhir 120 menit setelah pemberian beban. Hasil pengukuran glukosa darah dimasukkan dalam tabel. Perlakuan selanjutnya dengan selang waktu yang telah ditentukan, glukosa murni digantikan dengan puding ubi jalar tanpa penambahan buah naga merah, selanjutnya digantikan dengan puding ubi jalar putih dengan penambahan buah naga merah berturut- turut dengan proporsi $25 \%, 50 \%$, dan $75 \%$. Jarak setiap penelitian untuk masing- masing pangan adalah 4 hari. Sedangkan subjek penelitian untuk daya terima adalah 25 orang pasien diabetes melitus. Uji laboratorium digunakan untuk mengetahui kadar karbohidrat dengan metode Luff Schoorl dan serat puding ubi jalar dan buah naga merah dengan metode gravimetric. 
Tabel 1. Formulasi Pembuatan Puding

\begin{tabular}{|c|c|c|c|c|}
\hline Kelompok & Ubi Jalar Putih & Buah Naga Merah & $\begin{array}{l}\text { Tepung Agar- } \\
\text { Agar }\end{array}$ & Gula Diabetasol \\
\hline$K$ & 100 gram & - & 3,5 gram & 1 gram \\
\hline$P_{1}$ & 75 gram & $\begin{array}{c}25 \text { gram atau setara dengan } 25 \% \text { (dari } \\
\text { jumlah ubi jalar putih) }\end{array}$ & 3,5 gram & 1 gram \\
\hline$P_{2}$ & 50 gram & $\begin{array}{c}50 \text { gram atau setara dengan } 50 \% \text { (dari } \\
\text { jumlah ubi jalar putih) }\end{array}$ & 3,5 gram & 1 gram \\
\hline$P_{3}$ & 25 gram & $\begin{array}{c}75 \text { gram atau setara dengan } 75 \% \text { (dari } \\
\text { jumlah ubi jalar putih) }\end{array}$ & 3,5 gram & 1 gram \\
\hline
\end{tabular}

Teknik pengumpulan data penelitian ini menggunakan uji laboratorium yang meliputi uji indeks glikemik, kadar karbohidrat, dan kadar serat, selain itu pengumpulan data menggunakan form hedonic scale test untuk mengetahui daya terima puding. Alat yang digunakan uji indeks glikemik adalah glucometer (GlucoDr), test strip (GlucoDr), lancing device, blood lancets, dan alcohol swabs. Data disajikan dalam bentuk teks, tabel, dan grafik. Analisis data indeks glikemik menggunakan uji non parametrik Kruskall Wallis Test, jika signifikan dilanjutkan dengan uji Mann-Whitney. Kadar karbohidrat dan kadar serat menggunakan uji parametrik One-Way ANOVA, jika signifikan dilanjutkan dengan uji Bafferoni. Uji daya terima menggunakan uji non parametrik Friedman Test, jika signifikan dilanjutkan dengan uji Wilcoxon Signed Rank Test.

\section{HASIL DAN PEMBAHASAN}

Penentuan jumlah asupan puding untuk menguji indeks glikemik disetarakan dengan 50 gram available carbohydrate. Jumlah sampel yang diujikan pada 4 taraf perlakuan puding ubi jalar putih dengan penambahan buah naga merah sebesar $0 \%, 25 \%, 50 \%$, dan $75 \%$ secara berturut-turut adalah 200,24 gram; 233,32 gram; 286,20 gram; dan 349,90 gram. Indeks glikemik puding dikategorikan dalam kategori rendah karena memiliki skala atau angka $<55$. Indeks glikemik puding dengan 4 taraf perlakuan tersebut dapat dilihat pada Tabel 1.

Tabel 2. Indeks Glikemik Puding Ubi Jalar Putih dengan Penambahan Buah Naga Merah

\begin{tabular}{cccc}
\hline Perlakuan & $\begin{array}{c}\text { Puding Ubi Jalar } \\
\text { dengan } \\
\text { Penambahan Buah } \\
\text { Naga Merah }\end{array}$ & $\begin{array}{c}\text { Indeks } \\
\text { Glikemik }\end{array}$ & Kategori \\
\hline K & $0 \%$ & 37,75 & Rendah \\
P1 & $25 \%$ & 33,81 & Rendah \\
P2 & $50 \%$ & 32,81 & Rendah \\
P3 & $75 \%$ & 29,54 & Rendah \\
\hline
\end{tabular}

Berdasarkan hasil statistik Kruskall-Wallis Test dengan tingkat signifikasi $(\alpha)$ sebesar 0,05 didapatkan nilai $p$ value 0,845 menunjukkan tidak ada perbedaan yang signifikan dari penambahan buah naga merah terhadap indeks glikemik puding ubi jalar putih. Diabetes melitus adalah kumpulan gejala yang timbul pada seseorang yang mengalami peningkatan kadar gula darah akibat kekurangan hormon insulin secara absolut atau relatif. Penderita diabetes melitus membutuhkan makanan berindeks glikemik rendah. Indeks glikemik adalah skala atau angka yang diberikan pada makanan tertentu berdasarkan sebesarapa cepat makanan tersebut meningkatkan kadar gula darah.

Indeks glikemik dipengaruhi oleh beberapa faktor, yaitu tingkat gelatinisasi, bentuk fisik makanan, rasio amilosa dan amilopektin, kadar serat makanan, kadar gula sukrosa, tingkat keasaman, lemak dan protein, serta tingkat kematangan ${ }^{6}$. Semakin tinggi penambahan buah naga merah, indeks glikemik puding ubi jalar putih mengalami penurunan. Hal ini disebabkan oleh komponen buah naga merah yang memberikan efek hipoglikemik yang berfungsi untuk menyeimbangkan kadar glukosa darah.

Penelitian Hidayati (2017) menyatakan terjadi penurunan rerata kadar glukosa darah sebelum dan sesudah pemberian buah naga merah 200 gram selama 10 hari berturut-turut ${ }^{7}$. Berdasarkan hasil penelitian tersebut, indeks glikemik puding tergolong dalam kategori rendah. Perbedaan hasil kadar karbohidrat puding ubi jalar putih dengan penambahan buah naga merah 25\%, 50\%, dan 75\% dapat dilihat pada Gambar 1 . Berdasarkan hasil One-Way ANOVA dengan tingkat signifikasi $(\alpha)$ sebesar 0,05 didapatkan $p$ value 0,000 menunjukkan ada perbedaan secara signifikan kadar karbohidrat puding sehingga dilanjutkan dengan uji bafferoni yang menunjukkan keempat sampel memiliki perbedaan yang signifikan.

Selain berindeks glikemik rendah, penderita diabetes memerlukan makanan rendah karbohidrat dan tinggi serat. Karbohidrat berpengaruh terhadap peningkatan atau penurunan glukosa darah. Hal ini serupa dengan penelitian Baequny et al., (2015:691) yang menyatakan bahwa pola makan tinggi kalori berpengaruh terhadap peningkatan kadar gula darah penderita DMT2 di Puskesmas Bendan Kota Pekalongan ${ }^{8}$. Kadar karbohidrat puding mengalami penurunan seiring dengan tingginya penambahan buah naga merah sehingga puding dapat digunakan sebagai alternatif makanan selingan penderita diabetes agar gula darah penderita tidak naik secara drastis. Jaringan tubuh penderita diabetes tidak mampu menyimpan dan menggunakan gula, sehingga kadar gula darah dipengaruhi oleh tingginya konsumsi karbohidrat.

Hasil kadar serat puding ubi jalar putih dengan penambahan buah naga merah $25 \%, 50 \%$, dan $75 \%$ dapat dilihat pada Gambar 2. Berdasarkan hasil OneWay ANOVA dengan tingkat signifikasi $(\alpha)$ sebesar 0,05 didapatkan $p$ value 0,000 menunjukkan ada perbedaan secara signifikan kadar karbohidrat puding sehingga dilanjutkan dengan uji bafferoni yang menunjukkan keempat sampel memiliki perbedaan yang signifikan. 


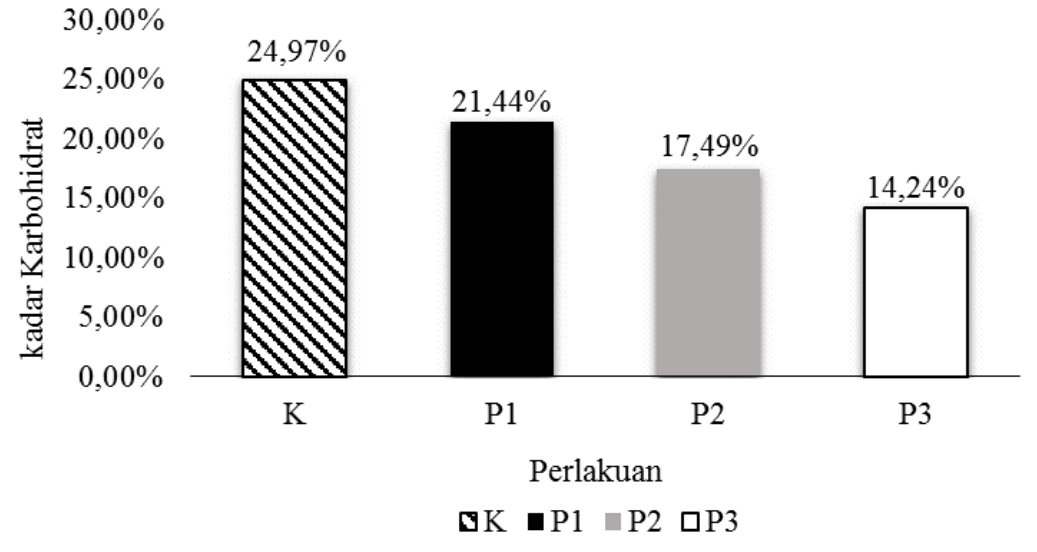

Gambar 1. Kadar Karbohidrat Puding

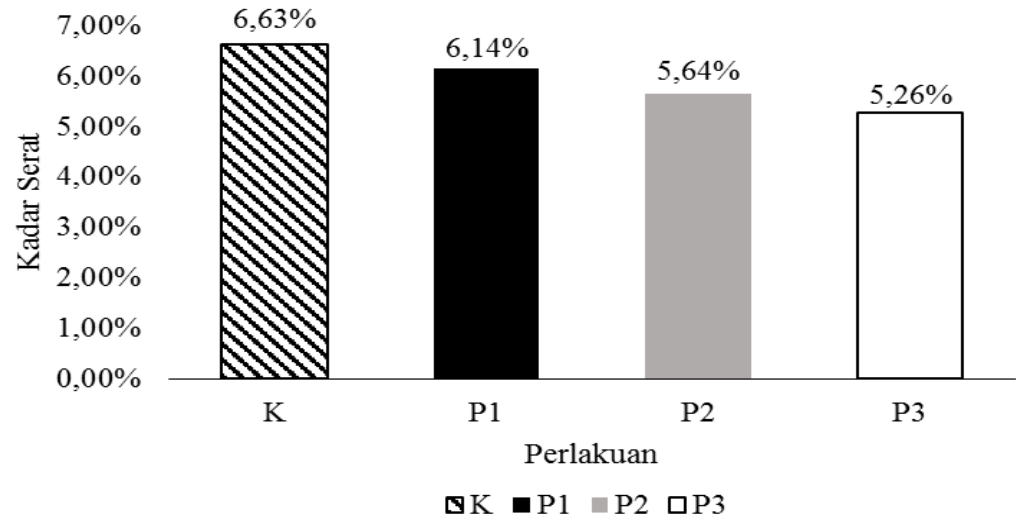

Gambar 2. Kadar Serat Puding

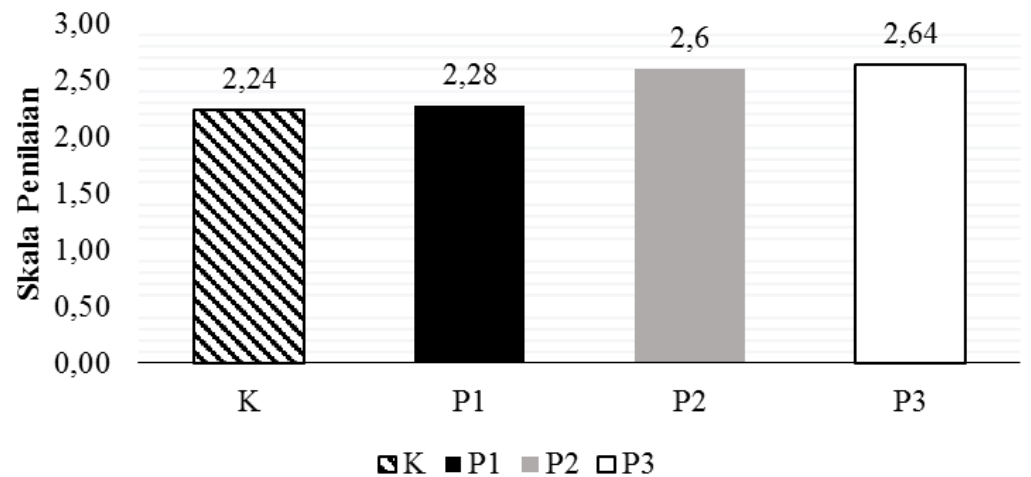

Gambar 3. Daya Terima Warna 


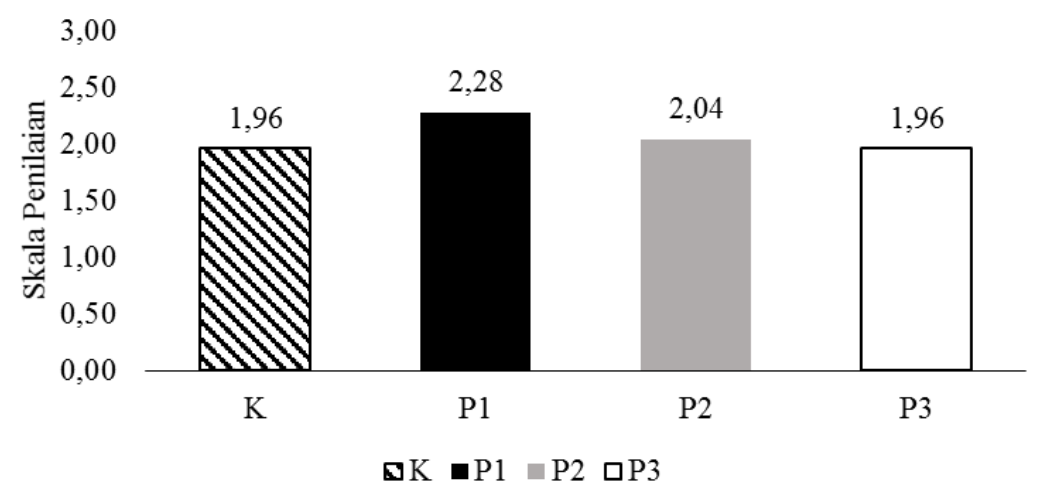

Gambar 4. Daya Terima Aroma

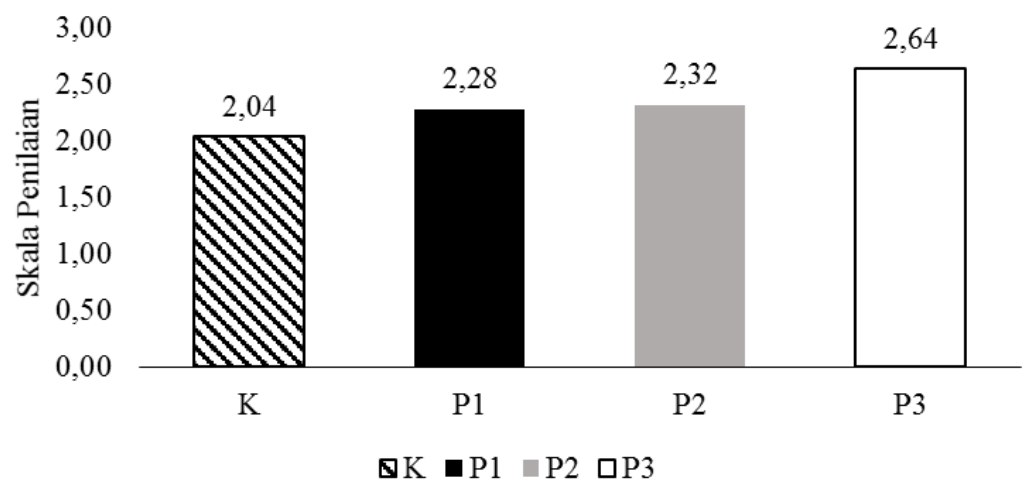

Gambar 5. Daya Terima Rasa

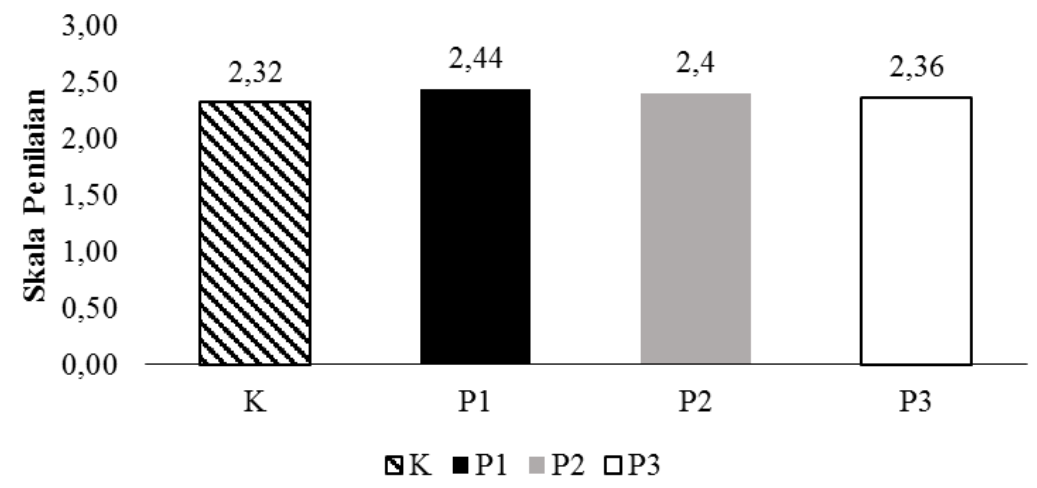

Gambar 6. Daya Terima Tekstur

Serat pangan memiliki manfaat bagi kesehatan. Menurut Santoso (2011:39) serat bermanfaat untuk mengontrol berat badan atau kegemukan, menanggulangi penyakit diabetes, mencegah gangguan gastrointestinal, mencegah kanker kolon, dan mengurangi tingkat kolesterol serta penyakit kardiovaskuler. Pada penelitian ini, kadar serat mengalami penurunan seiring dengan penambahan buah naga merah sehingga perlu adanya penelitian lanjutan untuk meningkatkan kadar serat pada puding agar dapat dijadikan sebagai alternatif makanan selingan untuk penderita diabetes. Terdapat penelitian serupa oleh Ramadhan et al., (2015:27) dimana semakin tinggi penambahan buah naga merah maka kadar serat fruit leather mengalami penurunan ${ }^{9}$.

Daya terima warna puding ubi jalar putih dengan penambahan buah naga merah dapat dilihat pada Gambar 3. Berdasarkan hasil analisis non parametric Friedman Test dengan tingkat signifikasi $(\alpha)$ sebesar 0,05 didapatkan $p$ value 0,064 artinya tidak terdapat perbedaan daya terima warna yang signifikan. 
Daya terima warna puding ubi jalar putih dengan penambahan buah naga merah dapat dilihat pada Gambar 4. Berdasarkan hasil analisis non parametric Friedman Test dengan tingkat signifikasi $(\alpha)$ sebesar 0,05 didapatkan $p$ value 0,067 artinya tidak terdapat perbedaan daya terima warna yang signifikan. Daya terima warna puding ubi jalar putih dengan penambahan buah naga merah dapat dilihat pada Gambar 5. Berdasarkan hasil analisis non parametric Friedman Test dengan tingkat signifikasi $(\alpha)$ sebesar 0,05 didapatkan $p$ value 0,001 artinya terdapat perbedaan daya terima warna yang signifikan sehingga dilanjutkan uji Wilcoxon Signed Rank Test. Daya terima warna puding ubi jalar putih dengan penambahan buah naga merah dapat dilihat pada Gambar 6. Berdasarkan hasil analisis non parametric Friedman Test dengan tingkat signifikasi $(\alpha)$ sebesar 0,05 didapatkan $p$ value 0,775 artinya tidak terdapat perbedaan daya terima warna yang signifikan.

Suatu produk pangan baru harus diuji organoleptik untuk mengetahui apakah suatu produk atau komoditi diterima dimasyarakat. Pengujian organoleptik merupakan pengujian berdasarkan penginderaan. Pengujian organoleptik dipengaruhi faktor internal dan eksternal. Pengujian organoleptik dilakukan oleh 25 panelis yang telah sesuai dengan kriteria inklusi dan ekslusi. Uji daya terima pada makanan meliputi warna, aroma, rasa, dan tekstur. Warna pada makanan merupakan faktor penting yang harus diperhatikan dalam seni tata saji makanan yang dapat menggugah selera ${ }^{10}$. Puding dengan penambahan buah naga $75 \%$ merupakan puding yang diterima oleh panelis dari segi warna. Semakin tinggi penambahan buah naga merah maka warna puding semakin merah dan menarik. Buah naga merah mengandung zat warna alami yaitu antosianin. Hal ini serupa dengan penelitian yang dilakukan oleh Wahyuni (2012:83) bahwa semakin banyak daging buah naga merah yang ditambahkan dalam jenang, maka panelis semakin menyukai warna puding tersebut ${ }^{11}$. Aroma makanan merupakan sifat sensori yang paling sulit diklasifikasikan dan dijelaskan. Semakin rendah penambahan buah naga merah maka panelis semakin menyukai dari segi aroma puding. Hal ini dikarenakan semakin tingginya penambahan buah naga merah maka aroma langu pada buah naga merah semakin tercium. Rasa adalah suatu sensasi yang muncul dan disebabkan oleh komponen kimia yang volatile dan non volatile yang berasal dari alam maupun sintesis dan timbul pada saat makan dan minum. Rasa merupakan hasil kerja pengecap rasa yang terletak di lidah, pipi, kerongkongan, atap mulut, yang merupakan bagian dari cita rasa ${ }^{12}$. Daya terima rasa pada puding ubi jalar yang paling disukai adalah penambahan buah naga $75 \%$. Hal ini selaras dengan penelitian yang dilakukan oleh Wahyuni (2012:84) bahwa semakin tinggi penambahan buah naga merah, panelis lebih menyukai produk jenang tersebut. Daya terima tekstur juga merupakan salah satu sifat fisik bahan pangan yang turut menentukan cita rasa makanan karena sensitivitas indera. Puding ubi jalar dengan $25 \%$ penambahan buah naga merah merupakan puding yang paling disukai dari segi tekstur, hal ini dikarenakan karena kandungan air tidak terlalu banyak dibandingkan dengan penambahan buah naga merah
$50 \%$ dan $75 \%$, sedangkan puding tanpa penambahan buah naga merah teksturnya lebih keras dan kandungan airnya sedikit.

\section{KESIMPULAN}

Kesimpulan penelitian yaitu terdapat perbedaan indeks glikemik puding ubi jalar putih dengan penambahan buah naga merah, meskipun tidak signifikan secara analisis statistik. Kadar karbohidrat dan kadar serat puding ubi jalar putih mengalami penurunan seiring tingginya penambahan buah naga merah. Puding ubi jalar dengan penambahan $75 \%$ buah naga merah merupakan puding yang paling disukai oleh panelis. Namun berdasarkan analisis statistik, hanya daya terima rasa yang memiliki perbedaan yang signifikan, sedangkan daya terima warna, tekstur, dan aroma tidak berbeda secara signifikan. Adapun saran yang dianjurkan adalah perlu adanya penelitian lanjutan efek perubahan gula darah pada penderita diabetes melitus setelah pemberian puding. Selain itu, perlu adanya penelitian lanjutan untuk meningkatkan kadar serat, kadar protein, dan kadar lemak puding sehingga puding menjadi salah satu alternatif makanan selingan yang berindeks glikemik rendah, kadar karbohidrat rendah, dan kadar serat rendah.

\section{ACKNOWLEDGEMENT}

Penulis mengucapkan terimakasih atas partisipasi pasien di Klinik dr. Suherman Universitas Muhammadiyah Jember dan mahasiswa Fakultas Kesehatan Masyarakat Universitas Jember.

\section{CONFLICT OF INTEREST}

Semua penulis tidak memiliki conflict of interest terhadap artikel ini.

\section{REFERENS}

1. Almatsier, S. Penuntun Diet. (PT Gramedia Pustaka Utama, 2010).

2. Rafanani, B. Buku Pintar Pola Makan Sehat dan Cerdas Bagi Penderita Diabetes. (Araska, 2013).

3. Santoso, A. Serat Pangan (Dietary Fiber) dan Manfaatnya bagi Kesehatan. Magistra 35-40 (2011).

4. Wiardani, N. K., Moviana, Y. \& Puryana, I. G. P. S. Jus Buah Naga Merah Menurunkan Kadar Glukosa Darah Penderita DMT2. J. Skala Husada 11, 59-66 (2014).

5. Hanafiah, K. A. No Title. (Raja Grafindo Persada, 2005).

6. Sidik, A. J. Perbedaan indeks glikemik dan beban glikemik dua varian biskuit. (Universitas Islam Negeri Syarif Hidayatullah Jakarta, 2014).

7. Hidayati, A. R. Darah Pasien Diabetes Melitus Tipe II. (Universitas 'Aisyiyah Yogyakarta, 2017).

8. Baequny, A., Harnany, A. S. \& Rumimer, E. Pengaruh Pola Makan Tinggi Kalori terhadap Peningkatan Kadar Gula Darah pada Penderita Diabetes Mellitus Tipe 2. 4, 687-692 (2015). 
9. Ramadhan, M. R., Harun, N. \& Hamzah, F. Kajian Pemanfaatan Buah Naga Merah (Hylocereus polyrhizus) dan Mangga (Mangifera indica Linn) dalam Pembuatan Fruit Leather. SAGU 14, 23-31 (2015).

10. Astawan, M. \& Kasih, A. L. Khasiat Warna-Warni Makanan. (PT Gramedia Pustaka Utama, 2008).
11. Wahyuni, R. Pemanfaatan Buah Naga Super Merah ( Hylocereus costaricensis ) Dalam Pembuatan Jenang dengan Perlakuan Penambahan Daging Buah yang Berbeda. J. Teknol. pangan 4, 71-92 (2012).

12. Drummond, K. E. \& Brefere, L. M. Nutrition Food Service and Culinary Profesional's. (John Wiley and Sons's Inc, 2014). 